\title{
A Comparative Study of Sino-Japan English Teaching: Reflections and Enlightenment
}

\author{
Yufeng Meng \\ Foreign Languages College \\ Changchun University \\ Changchun, China
}

\begin{abstract}
China and Japan share many historical origins in culture and language and have some similar theories and practices in the educational thoughts and teaching patterns. The paper compared the English teaching systems in China and Japan in terms of the curriculum, teaching objective, teaching mode and teaching effect, analyzed the common problems of English teaching in both countries, explored the educational, cultural and language factors that lead to the "high investment, low efficiency" in the English education by citing and analyzing TOEFL and IELTS scores, and finally summarized the enlightenment of Japan's English teaching reform and practices on China. Although both countries suffer from the same problems such as dumb English, exam-oriented teaching and low efficiency, Japan's reformations on English teaching, especially the assessment system and staff training requirements, can be a good reference for China's English teaching reform to raise the general level of English teaching and learning in China.
\end{abstract}

Keywords-Sino-Japan English teaching; comparison; reflections; enlightenment

\section{INTRODUCTION}

China and Japan share many profound historical origins in culture and language, and have the same or similar theories and practices in educational thoughts and teaching patterns. Both countries regard the popularization of English education as a strategy to improve the national quality, revitalize the national economy and integrate into the international community. There are both similarities and differences in their English teaching and learning, therefore, a comparative study of English education in the two countries will help to strengthen the mutual understanding and learning from each other, so as to promote the development and improvement of English education level in China.

\section{COMPARISON OF SINO-JAPAN ENGLISH TEACHING}

\section{A. Teaching Curriculum}

English has become a foreign language with the largest number of learners in the world. English education is taking up more and more important position in the education systems of both China and Japan, whose emphasis on and investment in it have reached an unprecedented level.

Since the 1990s, China's English education has made remarkable progress, especially in the development of syllabus, textbooks and proficiency tests. English has become part of elementary education, and one of the three main subjects of high school and college entrance examinations. Due to the guidance issued by Ministry of Education in 2001, English course has been offered in primary schools from grade 3 since the autumn of 2002, and in some developed areas such as Shanghai and Beijing, English teaching starts even earlier. At present, English teaching runs through primary, secondary, and higher education in China.

Similarly, English also plays an important role in Japan's education system. Since the 1980s, Japan has been reforming the English teaching system in order to cultivate more and more international talents. JET Program (Japan Exchange and Teaching Program), namely, the recruitment of a large number of foreign young people to Japan for foreign language teaching and research, has especially played an important role in promoting Japan's economic development and foreign language teaching reform. A Conceived Strategy on Training Japanese to Communicate in English (2002) and the subsequent A Plan of Action for Training Japanese to Communicate in English specified the requirements for students' English proficiency from the middle school to college English education. [1] Since then, English has been made a compulsory course in middle schools, with weekly class hours increased, and "English conversation" added from grade 3.

In 2017, the newly revised Learning Guidelines for Primary Schools proposed to start English teaching from grade 3 and 4 to cope with the trend of internationalization. Students would be exposed to "foreign language teaching activities" with focus on "listening and speaking" and cultivating their interest. The English activity courses would start from grade 3 and 4 , while in grade 5 and grade 6 , "reading and writing" would be added to English classes, making English a formal subject in public primary schools. [2]

\section{B. Teaching Objective}

Both China and Japan take intercultural communication ability as the general teaching objective of their English education. The English Curriculum Standards for Compulsory Education launched in 2017 in China points out that the English curriculum system aims to cultivate students' comprehensive ability of language application. It sets up the overall and hierarchical goals from five aspects, including language skills, language knowledge, emotional attitude, 
learning strategies and cultural awareness. [3] College English Curriculum Requirements issued by the Ministry of Education in 2007 emphasizes that the teaching goal of college English is to cultivate students' integrated English proficiency, especially listening and speaking ability, and enhance their independent learning ability and improve their comprehensive cultural competence, so as to meet the needs of China's development and international exchanges. [4]

Learning Guidelines for Primary and Secondary Schools re-formulated by Japan's MEXT proposes that the goal of English education is to deepen the understanding of the language and culture of English-speaking countries, and to cultivate students' awareness of active communication. The Conceived Strategy and Plan of Action also clearly state that the general goal of English education is to train Japanese to communicate in English, with emphasis on students' communication skills in listening, speaking, reading and writing. Plan of Action requires that English listening and speaking be included in the entrance examinations for senior high schools and universities, in order to change the domination of grammar and reading tests in the past, and to emphasize the cultivation of integrated communicative competence in English teaching.

\section{Teaching Mode}

China and Japan also show some similarities in English teaching mode, such as the reading-centered class, the examoriented inclination, the emphasis on learners' knowledge accumulation but neglect of the communicative ability cultivation.

The traditional English teaching in China often focuses on language knowledge such as pronunciation, grammar and vocabulary. This mode enables students to master a lot of knowledge about vocabulary and grammar, thus greatly improve their reading ability, but is unable to significantly improve their English communicative competence. Although in recent years, the learner-centered teaching mode has been much emphasized and applied, such as TBLT, communicative approach, multimedia teaching, network teaching, flipped classroom and so on, yet there is still a long way to go for a great improvement of the teaching effect, if the traditional entrance examinations for high school and college do not change .

Likewise, English teaching in Japan has long been examoriented. The English class in middle schools is mainly based on reading and translation, which is mostly directed by the college entrance examination. In recent years, Japan has been trying to reform English teaching from the traditional examoriented to application-oriented education. The curriculum is also becoming more and more practical. Practical courses such as oral English and interpretation have been added to all stages of education. In line with the Action Plan, English teaching in Japan is gradually shifting to a new mode, that is, English teaching in schools supplemented by language institutions. In addition, a series of reform measures have been taken, for example, over half of the classroom teaching must be in English; 10,000 high school students are selected annually to study abroad; during undergraduate and graduate studies, each student will be given the opportunity to study abroad for one year and the credits will be recognized by both sides. [5] These measures have, to some extent, improved the English proficiency of Japanese students.

\section{Teaching Effect}

Japan and China have both invested a lot in English teaching and reform, yet it seems to have not achieved the desirable effect. The English education in both countries seems to have been stuck in a cycle of "high investment, low efficiency", mainly reflected in the learners' insufficient language communicative competence, or “dumb English”, and the low-quality writing. Although great importance has been attached to the cultivation of English listening and speaking abilities, the scores of TOEFL and IELTS tests show that the English listening, speaking, reading and writing abilities of Chinese and Japanese learners do not even reach the global average level, as shown in TABLE I and TABLE II below.

According to the 2015 scores report released by ETS, in terms of TOEFL average total, China ranks 17th among 30 Asian countries and regions, while Japan ranks 26th. Since 2010, TOEFL scores of Chinese examinees have basically remained at 77, without significant improvement up to now. Average scores for listening and speaking have always been relatively low for Chinese candidates. The largest gap in scores between Chinese and global candidates appears in listening test. The situation is even worse for Japanese examinees, whose average total has remained among the last in Asia for years, especially in the speaking test.

According to the 2015 IELTS report (for Academic), among the top 40 countries and districts, Mainland China ranks the 33rd place with an average total score of 5.7, much lower than the first place with a score of 7.3. Moreover, the results of four individual tests were lower than the average level of Top 40, especially the average scores of listening and speaking. Japan was no better than China, though the speaking and total scores are slightly higher.

TABLE I. COMPARISON OF 2015 TOEFL SCORES

\begin{tabular}{|l|c|c|c|c|c|}
\hline \multirow{2}{*}{ Place of Origin } & \multicolumn{5}{|c|}{ Score } \\
\cline { 2 - 6 } & Reading & Listening & Speaking & Writing & Total \\
\hline P. R. China & 20 & 18 & 19 & 20 & 78 \\
\hline Japan & 18 & 17 & 17 & 18 & 71 \\
\hline Total Group & 20.3 & 19.9 & 20.3 & 20.6 & 81 \\
\hline
\end{tabular}

TABLE II. COMPARISON OF 2015 IELTS SCORES

\begin{tabular}{|l|c|c|c|c|c|}
\hline \multirow{2}{*}{ Place of Origin } & \multicolumn{5}{|c|}{ Score } \\
\cline { 2 - 6 } & Listening & Reading & Writing & Speaking & Total \\
\hline P. R. China & 5.9 & 6.1 & 5.3 & 5.4 & 5.7 \\
\hline Japan & 5.9 & 6.1 & 5.3 & 5.6 & 5.8 \\
\hline Total Group & 6.2525 & 6.165 & 5.6525 & 6.19 & 6.135 \\
\hline
\end{tabular}

TOEFL and IELTS are two well acknowledged English proficiency tests for non-native speakers due to their scientific, authoritative and objective test content and evaluation system. Although the scores of the tests cannot be taken completely as an evaluation standard of English teaching level, yet, to some 
degree, they can reflect the same problem of "high investment, low efficiency" in the English education of both countries.

\section{REFLECTIONS ON TIME-CONSUMING, INEFFICIENT ENGLISH EDUCATION IN CHINA AND JAPAN}

The time-consuming, inefficient English teaching in both countries can be attributed to many factors, such as inappropriate teaching method, lack of foreign language environment, poor quality of teaching staff, inefficient evaluation system, negative transfer of mother tongue, and lack of learning motivation, etc. , among which 3 common factors are listed below.

\section{A. The disjunction between Objective and Practice}

Although communication is established as the goal of English teaching, the traditional teaching mode can hardly be changed in a short time. At present, the exam-oriented mode still dominates the English education in both countries. Teaching is organized mainly for examination, but the examination cannot effectively assess student's integrated competence. English teaching emphasizes language knowledge but neglects listening and speaking training. Much effort is put on reading and test-taking skills instead of communication and application, hence the lack of communicative competence.

In China, the listening test has been included in the college entrance examination, but only takes up a small portion, while the speaking test is merely for specific majors. English is taught mostly in Chinese, with teachers dominating the class. Doing exercises, memorizing model essays and sentences become the most effective means for exams, which hinders not only students' learning motivation, but also their thinking ability. The inadequate language input in teaching inevitably results in students' poor language output. The poor performance in writing and speaking in IELTS and TOEFL is largely due to this long-term learning habits and teaching mode.

Japan's college admission examination also focuses on English grammar, reading and translation, but rarely involves oral communication. English teaching in schools mainly focuses on language knowledge, taught mostly in Japanese. Although the JET program recruits a large number of foreign teachers each year for public secondary schools, which renders Japan the highest proportion of foreign English teachers in the world, yet restricted by educational laws and regulations, most foreign teachers can only act as assistant language teachers, thus playing only a limited role in the exam-oriented education.

\section{B. Negative Effect of Language Environment}

China and Japan are both countries of single official language. Although both were invaded or colonized by other countries in history, they were never conquered or assimilated in language. The powerful mother tongues might hinder people's acceptance and learning of English. Moreover, the great difference between the mother tongue and the English language makes it difficult for people to learn English. Chinese, Japanese and English belong to completely different language systems, with totally different pronunciation, intonation and sentence structures. Therefore, the mother tongue's negative transfer on English learning is obvious. [6] In the process of learning, students will unconsciously transfer their mother tongue pronunciation, grammar, and structure to English expression, leading to poor pronunciation, incoherent and broken English expression, language deficiency, or Chinese / Japanese-styled English, etc.

In addition, both countries lack the English environment. English is rarely used in daily life and work, which results in people's low motivation for learning English and slow improvement of English communication. Besides, Japan has a well-developed and advanced translation industry, with thousands of institutions whose business covers all walks of life, ranging from academic research, national news to legal contracts, from overseas negotiation to visits by foreign guests All practical demands for English can be solved through translation professionals, which might be another cause for the lack of motivation of English learning in Japan.

\section{Negative Transfer of National Culture}

To some extent, the national culture of China and Japan has also exerted a negative transfer effect on English education and learning. Both countries have a similar experience of foreign invasions in history; both have a strong nationalism and historical complex of preventing western languages from invading the traditional culture. Deep down in their hearts, the Japanese seem to still maintain the idea of language purity, that's why they attach more importance to reading and translation as a means of international exchange. The same is true with English education in China.

In addition, due to the national temperament of shyness, and a culture of perfectionism in their education, Japanese students are reluctant to make mistakes. If they cannot speak English perfectly, they would rather not speak at all, which also hinders their English learning and communication to a certain extent. English education in China faces similar cultural barriers.

\section{ENLIGHTENMENT TO ENGLISH EDUCATION IN CHINA}

Although English education in Japan faces some common problems with China in many aspects, its advanced educational concepts and teaching practices can provide useful references for English teaching reform in China.

\section{A. Making More Scientific, Coherent Teaching Objectives}

Japan's Conceived Strategy and Plan of Action have established a consistent English education system from primary to higher education with a clear hierarchy, distinct features, and close connection. They have also formulated a set of coherent teaching guidelines: the primary stage focuses on interest in English and good learning habits; the secondary stage requires students to achieve the level of communicating and expressing their ideas in English; the higher education mainly cultivates students' communicative competence in their respective professional fields. 
However, English education in China seems to lack a scientific cohesion of the objectives among various stages, with teaching content sometimes overlapping. For example, English teaching in college and postgraduate stage still stresses language knowledge, neglecting English teaching in professional fields. Compared with Japanese undergraduates and postgraduates, Chinese students are lacking in competence of English academic literature reading, communication, and research innovation, so it is imperative to establish an English education system with scientifically hierarchal and properly connected objectives.

\section{B. Reforming Assessment System, Improving Teaching Quality}

To solve the drawbacks of "exam-oriented education", the Japanese government has taken many measures to improve the English teaching evaluation system, which includes reforming the high school and college entrance examination by adding listening and speaking tests, reforming the enterprise recruitment system to assess the applicants' ability of using English, acknowledging off-campus English test scores such as TOEFL and TOEIC for college admission to weaken the monopoly of the college entrance examination. Above all, the STEP test, or the English proficiency test administered by the Society for Testing English Proficiency, has long been considered in Japan as a benchmark to measure people's ability to communicate in English. It has 7 levels, among which Grade Pre-1 and Grade 1 correspond to the level of CET-4 and CET-6 in China. It requires that Grade 3 and above have an interview test in addition to the paper test. Such measures can motivate English teaching to put more emphasis on the cultivation of oral communication competence.

China' English assessment system has many drawbacks. The monopoly of the college entrance examination has made the teaching neglect communicative competence training. The oral test is not obligatory for the CET-4 and CET-6. Tests for English majors, TEM-4 and TEM-8, do not require mandatory oral examination either. Many students who have passed those examinations are unable to communicate fluently in English. Therefore, it is imperative to reform the English teaching evaluation system in China. Japan's successful experiences can be a good reference, such as adjusting the test content, diversifying evaluation forms, and establishing a scientific and effective assessment system for English proficiency. Up to now, some progress has been made. The China Standards of English was officially released by the Ministry of Education in 2018. It is the first English proficiency standard for Chinese learners, expecting to solve the problems that exist in our current assessment system. Yet, there is still a long way to go before the evaluation standards can be realized in tests, and help improve the quality of English teaching and learning.

\section{Strengthening Staff Training, Improving Qualification}

Teachers' ability largely determines the quality of education. In recent years, teaching staff development has been strengthened in China, but compared with Japan, there is still much deficiency in on-the-job training, recruitment of foreign teachers, and sponsoring teachers' overseas learning and research, etc. In addition, China has not yet set the entry standard for English teachers' language proficiency, nor a unified vocational skills standard for in-service teachers. Diploma is the first concern when schools recruit teachers. Whereas, Japan's MEXT has set such a standard, which specifically requires English teachers to achieve at least the Grade Pre-1 in the STEP test, or a score of 550 in TOEFL or 730 in TOEIC, thus urging teachers to improve their language skills. China's education authorities ought to explore and establish a proper and scientific certification system for English teaching qualification, not only in line with international standards, but also with distinct Chinese characteristics, so as to raise the general level of English teachers in China.

\section{CONCLUSION}

English education in China and Japan have similarities in teaching objective and teaching mode, and both are troubled by the problems of dumb English, exam-oriented teaching and "high investment, low efficiency". However, some advanced ideas and specific measures in Japan's English education system, especially the assessment system and staff training program can be applied in China's English teaching practice, so as to improve the English teaching to cultivate more and more young talents with international vision and intercultural communication competence.

\section{REFERENCES}

[1] Yurui Wang, and Yuxiu Zhang, “A conceived strategy on training Japanese to communicate in English,” J. Studies in Foreign Education. vol. 30, No. 10, pp. 18-20, Oct. 2003. (In Chinese)

[2] Dawei Liu, "Discussion on the English education of primary school in Japan and the enlightenment to China," J. The Modern Education Journal. vol. 175, No. 1, pp.49-52, .2011. (In Chinese)

[3] Ministry of Education of P. R. China, English Curriculum Standards for Compulsory Education, Beijing: Beijing Normal University Press, 2017.

[4] Ministry of Education of P. R. China, College English Curriculum Requirements, Shanghai: Shanghai Foreign Language Education Press, 2011.

[5] Xiaobing Li, "Problems and visions reflected through a comparison of Sino-Japan English education,” J. China Off-campus Education. No. 12, pp. 452-453, 2009. (In Chinese)

[6] Shuang Ma, “A Study on Chinese students' negative learning tendencies,” J. Journal of Shenyang Normal University, No. 1, pp.38-41, 2016. (In Chinese) 